\title{
Analyzing Strategic Factors Associated with Issuance of Environmental Liability Insurance Policy in Developing Countries using SWOT and QSPM
}

\author{
Mahnaz Mirza Ebrahim Tehrani
}

\begin{abstract}
In recent years, environmental pollution is one of the most commonly discussed topic in international scene. Environmental pollution and its associated aspects are not limited to the location of occurrence, but inevitably influence other regions too; as it says: "There is one earth for all". In other hand Environmental pollution is one of the most commonly discussed topics in today's national and international political societies in which increasing efforts are being made. Environmental pollution and its associated aspects are not limited to location of accident but inevitably influence other regions. Emission of carbon dioxide into the atmosphere or transfer of nitrates, and other hazardous chemicals into the rivers, seas and ocean waters can suggest such claim. Due to the lack of associated rules, criteria and regulations for issuance of environmental liability insurance, QSPM (Quantitative Strategic Planning Matrix) technique was applied in this study to introduce strategic factors required for such analysis. There are ten integrated strategies. The essential strategy is using legal tools to assess environmental risks in different industries. Results show that we need raising awareness of environmental accidents outcomes, which is concerned by insurance companies at developing countries.
\end{abstract}

Index Terms-Environmental pollution, hazard, QSPM, Internal and external factors, SWOT.

\section{INTRODUCTION}

Until 1972, due to the lack of appropriate environmental legislation and rules, there were no insurance policies on environmental related issues. Passing acts associated with clean air, water, resource conservation and restoration, gave the way for introducing environmental liability insurance policies such as environmental response, compensation issues, liability, etc. Enactment of natural resources conservation and restoration rules paves the way for introducing insurance which can cover gradual pollution losses. Since 1986, insurance industries undertook essential environmental liabilities for their potential customers. Nowadays in Europe, experts and authorities focus on development of environmental rules for defective products [1]. Increasing knowledge of environmental risk management indicated that environmental liability insurance should cover financial resources for compensation of past environmental pollution losses, natural resources losses, and harmful effects of polluting industries, and emotional distress of people who were forced to leave their house because of chemical pollution, etc. In so many cases environmental

Manuscript received July 18, 2016; revised December 15, 2016.

Mahnaz Mirza Ebrahim Tehrani is with Islamic Azad University, Iran (e-mail: tehrani.mah@gmail.com). liability insurance has provided a safe and healthy work environment for industries. Regarding technological achievements and management developments, environmental liability insurance is a tool for reducing potential hazards of industrial units specially polluting industries [2].

TABLE I: INTERNAL AND EXTERNAL FACTORS OF ISSUING ENVIRONMENTAL LIABILITY INSURANCE POLICY

\begin{tabular}{ll}
\hline \multicolumn{1}{c}{ Weaknesses(internal) } & \multicolumn{1}{c}{ Strengths(internal) } \\
\hline \hline $\begin{array}{l}\text { Lack of awareness about environmental } \\
\text { damages }\end{array}$ & Existing of Domestic experts \\
\hline $\begin{array}{l}\text { Environmental issues are not a priority } \\
\text { in industries }\end{array}$ & $\begin{array}{l}\text { Existence of civil liability } \\
\text { insurance in different existing } \\
\text { insurance policies }\end{array}$ \\
\hline Lack of experienced experts in order to & $\begin{array}{l}\text { Different methods and } \\
\text { techniques environmental risk } \\
\text { assessment are available }\end{array}$ \\
\hline issue environmental liability insurance
\end{tabular}

Lack of environmental experts in insurance companies

Occurrence of chain accidents and inevitability of its outcomes

Presence of different field in environmental universities

Uninsurable accidents (like natural

disasters)

\begin{tabular}{ll}
\hline \multicolumn{1}{c}{ Threats(external) } & \multicolumn{1}{c}{ Opportunities(external) } \\
\hline $\begin{array}{l}\text { No-obligation quote for issuance of } \\
\text { environmental liability insurance } \\
\text { policy exist }\end{array}$ & $\begin{array}{l}\text { Availability of environmental } \\
\text { rules and standards }\end{array}$ \\
\hline $\begin{array}{l}\text { Decision makers' focus on economic } \\
\text { objectives }\end{array}$ & $\begin{array}{l}\text { Presence of a government } \\
\text { organization (DOE) }\end{array}$ \\
\hline $\begin{array}{l}\text { Tax policy does not motivate industries } \\
\text { for new (environmental) insurance } \\
\text { policy }\end{array}$ & $\begin{array}{l}\text { Existing of Law of } \\
\text { Environmental Crimes }\end{array}$ \\
\hline $\begin{array}{l}\text { Potential environmental pollution by } \\
\text { industries supposing that insurance } \\
\text { companies will cover the cost to } \\
\text { remediate pollution }\end{array}$ & $\begin{array}{l}\text { Availability of insurance } \\
\text { lack of } \text { experience in dealing with } \\
\begin{array}{l}\text { environmental liabilities, especially in } \\
\text { claim management, which may cause } \\
\text { insurers financial loss }\end{array}\end{array}$ \\
\hline \hline
\end{tabular}

\section{METHOD}

In this research, environmental factors (both internal and external factors) which affect issuance of environmental insurance policy, was analyzed and identified. In other words, one should be aware of existing internal and external factors which affect insurance policy. Thus, one should assess all the strategic factors in order to detect all important and 
non-significant factors, and prioritize them. IFE and EFE matrices are evaluated to determine internal and external strategic factors [3].

\section{A. Identification of Internal and External Strategic Factors}

Internal Factor Evaluation matrix (IFE) is used to analyses Organizational Internal Factors (OIF). In other words, IFE evaluates strengths and weaknesses of organizational units. External Factor Evaluation matrix (EFE) analyses external factors and can be utilized to evaluate company's management performance in regards to identification of external opportunities and threats (Table I). As a result, after identifying internal and external factors, the strengths, weaknesses, opportunities, and threats of liability insurance policies can be identified, and a weight can be assigned to each factor, that ranges from 0.0 to 1.0 , depending on its importance. Zero means least important and one indicates most important [4].

TABLE II: IFE MATRIX

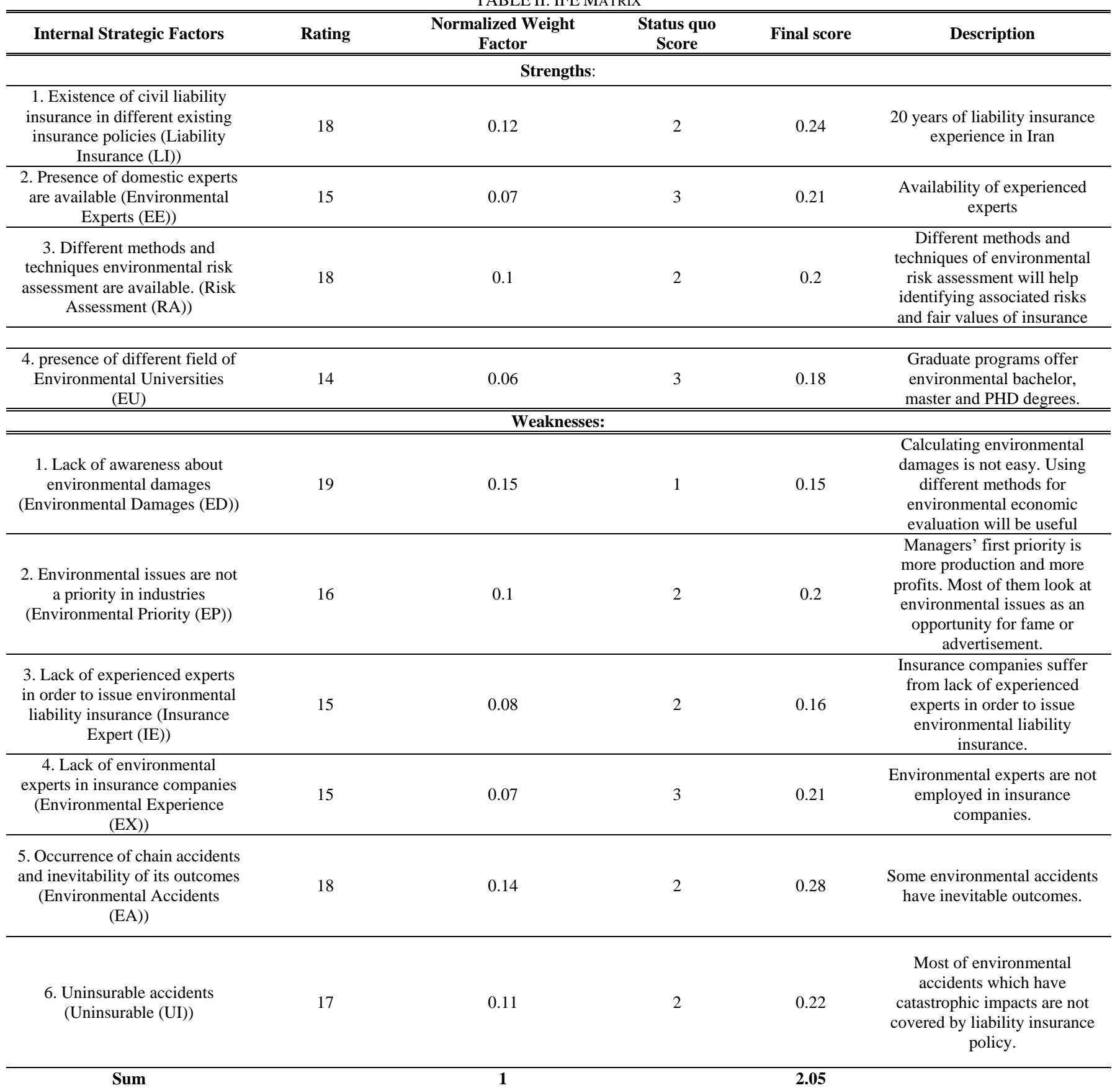

Status quo of each factor is rated from 1 to 5 (1=weak, $2=$ below average, $3=$ average, $4=$ higher than average, $5=$ well). These factors are called Existing Condition Score (ECM) [5]. Existing Status quo can help to manage weaknesses, strengths, threats, and opportunities in an organization. If the management wants to reduce weaknesses and threats, its assigned score will be high and vice versa. Thus each factor's final score is calculated by multiplying score of each row of organizational internal and external factors to its normalized weight. These values are written in a new column. After identifying internal factors, the strengths and weaknesses of environmental liability policy issuance can be highlighted [6].

Since environmental risks transfer in developing countries 
is a new topic, it is constantly being confronted with weaknesses and threats. On the other hand, opportunities, strengths and potential of these countries enable them to develop new insurance policies as well as environmental insurance policies [7].

\section{B. Forming Internal and External Factors Evaluation Matrices}

In order to form internal and external factor evaluation matrices, a score has been given to each item from zero to 20 , using expert opinions that reveal how well an insurance company can perform that item. This is called "Rating". In order to normalize the "Rating", equation 1, 2 has been used to evaluate normalize weight factors [8].

$$
\begin{gathered}
l=\frac{d}{d_{\max }} \\
d_{n}=\frac{d}{\left(\sum_{i=1}^{n} l_{i}\right) \times d \max }
\end{gathered}
$$

where $d n$ is the normalize factor and dmax is the maximum weight among strategic factors. It should be noted that the summation of normalize weight factors should be one.

To evaluate the existing condition, the experts' opinions (EXO) have been used to indicate the present situation by assigning the score from 1 to 5 .

$1=$ weak, $2=$ below average, $3=$ average, 4=higher than average, $5=$ well

The scores are called status quo.

\begin{tabular}{|c|c|c|c|c|c|}
\hline External Strategic Factors & Rating & $\begin{array}{c}\text { Normalized } \\
\text { Weight Factor } \\
\end{array}$ & $\begin{array}{c}\text { Status quo } \\
\text { Score } \\
\end{array}$ & Final score & Description \\
\hline \multicolumn{6}{|c|}{ Opportunities: } \\
\hline $\begin{array}{l}\text { 1. Availability of environmental } \\
\text { rules and standards (Environmental } \\
\text { Rules (ER)) }\end{array}$ & 18 & 0.12 & 2 & 0.24 & $\begin{array}{l}\text { Environmental rules and } \\
\text { standards provide an } \\
\text { opportunity for development of } \\
\text { insurance industry in terms of } \\
\text { environmental liabilities. }\end{array}$ \\
\hline $\begin{array}{l}2 \text { Department Of Environment } \\
\text { (DOE) }\end{array}$ & 17 & 0.10 & 4 & 0.4 & $\begin{array}{l}\text { Department of environment } \\
\text { which is responsible for } \\
\text { seeking penalties for } \\
\text { non-compliance in order to } \\
\text { meet environmental goals. }\end{array}$ \\
\hline $\begin{array}{l}\text { 3. Environmental crime acts } \\
\text { (Environmental crime (EC)) }\end{array}$ & 19 & 0.15 & 3 & 0.45 & $\begin{array}{c}\text { Environmental crime acts leads } \\
\text { industries to environmental } \\
\text { liability policies. }\end{array}$ \\
\hline $\begin{array}{l}\text { 4. Availability of insurance } \\
\text { agencies all over the country } \\
\text { (Insurance Development (ID)) }\end{array}$ & 15 & 0.09 & 3 & 0.18 & $\begin{array}{c}\text { Availability of insurance } \\
\text { agencies all over the country } \\
\text { will help domestic } \\
\text { employment and develop new } \\
\text { insurance policies. } \\
\end{array}$ \\
\hline \multicolumn{6}{|c|}{ Threats: } \\
\hline $\begin{array}{l}\text { 1. No-obligation quote for issuance } \\
\text { of environmental liability insurance } \\
\text { policy (Insurance Rules (IR)) }\end{array}$ & 19 & 0.17 & 3 & 0.51 & $\begin{array}{l}\text { Yet there is no-obligation } \\
\text { quote for issuance of } \\
\text { environmental liability } \\
\text { insurance policy in Iran. }\end{array}$ \\
\hline $\begin{array}{l}\text { 2. Decision makers' focus on } \\
\text { economic objectives (Economic } \\
\text { focus (EF)) }\end{array}$ & 17 & 0.12 & 2 & 0.24 & $\begin{array}{c}\text { Politicians and governors focus } \\
\text { on economic objectives than } \\
\text { environmental goals. }\end{array}$ \\
\hline $\begin{array}{c}3 \text { Tax policy does not motivate } \\
\text { industries for new (environmental) } \\
\text { insurance policy (Environmental } \\
\text { Motivation (EM)) }\end{array}$ & 14 & 0.11 & 3 & 0.33 & $\begin{array}{l}\text { Financial motivations are } \\
\text { needed for issuance of } \\
\text { environmental insurance } \\
\text { policy. }\end{array}$ \\
\hline $\begin{array}{l}4 \text { Potential environmental pollution } \\
\text { by industries supposing that } \\
\text { insurance companies will cover the } \\
\text { cost to remediate pollution } \\
\text { (Pollutant Industries (PI)) }\end{array}$ & 18 & 0.14 & 2 & 0.28 & $\begin{array}{c}\text { Sometimes issuance of an } \\
\text { insurance policy will cause } \\
\text { some industries not to focus on } \\
\text { environmental issues. }\end{array}$ \\
\hline $\begin{array}{l}\text { 5. Lack of experience in dealing } \\
\text { with environmental liabilities, } \\
\text { especially in claim management, } \\
\text { which may cause insurers financial } \\
\text { loss (Insurer's Experience (IX)) }\end{array}$ & 12 & 0.11 & 3 & 0.33 & $\begin{array}{l}\text { Small number of insurance } \\
\text { policies issued, and potential } \\
\text { risks of financial loss may } \\
\text { discourage insurance } \\
\text { companies and make them stop } \\
\text { issuance of environmental } \\
\text { liability insurance. }\end{array}$ \\
\hline Sum & & 1 & & 4.05 & \\
\hline
\end{tabular}

TABLE III: EFE MATRIX

The final score of each item can be evaluated by multiplying the normalize weight factor to present status. Tables II and III show the final score IFE and EFE matrices for all different defined items.

The summation of final scores for each matrix, can present the status of SWOT of insurance policy of environment. [9]
Since internal and external strategic factors evaluation matrices are used to identify importance of the factors and their prioritization, sum of their weighted scores have been calculated. The minimum is 1 , the maximum is 5 and the average is 3 . If the total IEF score is less than 3 , it means that issuance of environmental liability insurance has weaknesses 
due to internal factors [10]. Similarly, if the average of total EFE score is less than 3, it means that issuance of environmental liability insurance does not work as well in taking advantage of opportunities and dealing with threats. [11] The scores in Tables II and III were given in accordance with one expert opinion. In order to take the advantage of all experts ( 7 experts), the average weighted score of each item was evaluated using the average of evaluated scores, as presented in Table IV.

TABLE IV : COMPARING SURVEY RESULTS OF STRATEGIC FACTORS

\begin{tabular}{|c|c|c|c|c|c|c|c|c|c|c|c|}
\hline $\begin{array}{c}\text { Internal Strategic } \\
\text { Factors }\end{array}$ & Expert 1 & Expert 2 & Expert 3 & Expert 4 & Expert 5 & Expert 6 & Expert 7 & Average & $\mathrm{SD}^{1}$ & X-SD & $\mathrm{X}+\mathrm{SD}$ \\
\hline \multicolumn{12}{|l|}{ Strengths: } \\
\hline $\begin{array}{l}\text { 1. Existence of civil } \\
\text { liability insurance in } \\
\text { different existing } \\
\text { insurance policies } \\
\text { (Liability Insurance } \\
\text { (LI)) }\end{array}$ & 0.24 & 0.19 & 0.22 & 0.18 & 0.15 & 0.26 & 0.22 & 0.2 & 0.037 & 0.163 & 0.237 \\
\hline $\begin{array}{l}\text { 2.Presence of domestic } \\
\text { experts (Environmental } \\
\text { Experts }(\mathrm{EE}))\end{array}$ & 0.21 & 0.17 & 0.12 & 0.24 & 0.17 & 0.23 & 0.20 & 0.19 & 0.041 & 0.149 & 0.231 \\
\hline $\begin{array}{l}\text { 3. Different methods and } \\
\text { techniques of } \\
\text { environmental risk } \\
\text { assessment (Risk } \\
\text { Assessment are } \\
\text { available (RA)) }\end{array}$ & 0.2 & 0.19 & 0.11 & 0.17 & 0.21 & 0.22 & 0.17 & 0.18 & 0.036 & 0.144 & 0.216 \\
\hline $\begin{array}{l}\text { 4. Environmental } \\
\text { courses in universities } \\
\text { (Environmental } \\
\text { Universities (EU))are } \\
\text { practiced }\end{array}$ & 0.18 & 0.22 & 0.12 & 0.11 & 0.16 & 0.21 & 0.18 & 0.17 & 0.041 & 0.129 & 0.211 \\
\hline \multicolumn{12}{|l|}{ Weaknesses: } \\
\hline $\begin{array}{l}\text { 1. Lack of awareness } \\
\text { about environmental } \\
\text { damages } \\
\text { (Environmental } \\
\text { Damages (ED)) }\end{array}$ & 0.15 & 0.19 & 0.21 & 0.12 & 0.18 & 0.12 & 0.10 & 0.18 & 0.041 & 0.139 & 0.221 \\
\hline $\begin{array}{l}\text { 2. Environmental issues } \\
\text { are not a priority in } \\
\text { industries } \\
\text { (Environmental Priority } \\
(\mathrm{EP}))\end{array}$ & 0.2 & 0.24 & 0.12 & 0.18 & 0.15 & 0.22 & 0.18 & 1.29 & 0.040 & 1.25 & 1.33 \\
\hline $\begin{array}{l}\text { 3. Lack of experienced } \\
\text { experts in order to issue } \\
\text { environmental liability } \\
\text { insurance (Insurance } \\
\text { Expert (IE)) }\end{array}$ & 0.16 & 0.21 & 0.11 & 0.20 & 0.18 & 0.25 & 0.12 & 0.17 & 0.049 & 0.121 & 0.219 \\
\hline $\begin{array}{l}\text { 4. Lack of } \\
\text { environmental experts in } \\
\text { insurance companies } \\
(\text { Environmental } \\
\text { Experience }(\mathrm{EX}))\end{array}$ & 0.21 & 0.16 & 0.19 & 0.11 & 0.21 & 0.20 & 0.15 & 0.17 & 0.037 & 0.133 & 0.207 \\
\hline $\begin{array}{l}\text { 5. Occurrence of chain } \\
\text { accidents and } \\
\text { inevitability of its } \\
\text { outcomes } \\
\text { (Environmental } \\
\text { Accidents (EA)) }\end{array}$ & 0.28 & 0.18 & 0.19 & 0.19 & 0.22 & 0.19 & 0.21 & 0.208 & 0.034 & 0.174 & 0.242 \\
\hline $\begin{array}{l}\text { 6. Uninsurable accidents } \\
\text { (Uninsurable (UI)) }\end{array}$ & 0.22 & 0.21 & 0.18 & 0.22 & 0.24 & 0.24 & 0.12 & 0.204 & 0.042 & 0.162 & 0.246 \\
\hline Sum & 2.05 & 1.96 & 1.57 & 1.72 & 1.8 & 2.14 & 1.65 & 1.84 & 0.213 & 1.627 & 2.053 \\
\hline $\begin{array}{c}\text { External Strategic } \\
\text { Factors } \\
\end{array}$ & Expert 1 & Expert 2 & Expert 3 & Expert 4 & Expert 5 & Expert 6 & Expert 7 & Average & $\mathbf{S D}^{2}$ & X-SD & $\mathbf{X}+\mathrm{SD}$ \\
\hline \multicolumn{12}{|l|}{ Opportunities: } \\
\hline $\begin{array}{l}\text { 1. Availability of } \\
\text { environmental rules and } \\
\text { standards } \\
\text { (Environmental Rules } \\
(\text { ER)) }\end{array}$ & 0.24 & 0.22 & 0.14 & 0.18 & 0.20 & 0.19 & 0.12 & 0.18 & 0.042 & 0.138 & 0.222 \\
\hline $\begin{array}{l}\text { 2. Department of } \\
\text { Environment (DE) }\end{array}$ & 0.4 & 0.12 & 0.22 & 0.14 & 0.43 & 0.22 & 0.28 & 0.26 & 0.119 & 0.141 & 0.379 \\
\hline 3. Environmental crime & 0.45 & 0.43 & 0.25 & 0.22 & 0.40 & 0.29 & 0.34 & 0.34 & 0.09 & 0.25 & 0.43 \\
\hline
\end{tabular}


acts (Environmental

crime (EC))

4. Availability of

insurance agencies all

over the country

(Insurance Development

$\begin{array}{lll}0.18 & 0.22 & 0.12\end{array}$

0.13

0.4

0.29

0.19

0.22

0.098

0.122

0.318

(ID))

\section{Threats:}

1. no-obligation quote

for issuance of

environmental liability

insurance policy

0.5

0.32

0.6

0.23

0.55

0.32

0.42

0.42

0.13

0.29

0.55

(Insurance Rules (IR))

2. Decision makers'

focus on economic

objectives (Economic

0.24

0.19

0.12

0.18

0.12

0.14

0.10

0.15

0.049

0.101

0.251

3. Tax policy does not

motivate industries for

new (environmental)

insurance policy

$0.22 \quad 0.22$

$0.22 \quad 0.12$

0.14

0.14

0.2

0.24

0.072

0.168

$0 . .312$

Motivatio

4. Potential

environmental pollution

by industries supposing

that insurance

companies will cover the

0.28

0.2

0.19

0.12

0.18

0.055

0.125

0.235

pollution (Pollutant

Industries (PI))

5. Lack of experience in

dealing with

environmental

liabilities, especially in

claim management,

insurers financial loss

(Insurer's Experience

(IX))

\begin{tabular}{|c|c|c|c|c|c|c|c|c|c|c|}
\hline Sum & 4.05 & 2.92 & 2.08 & 1.51 & 6.16 & 1.93 & 2.27 & 2.98 & 1.62 & 1.36 \\
\hline
\end{tabular}

TABLE V: COMPARISON OF STRENGTHS AND OPPORTUNITIES (SO) Strengths

RA

EE

LI

\begin{tabular}{cll} 
Opportunities & RA & LE \\
\hline \hline ER & & \\
\hline DE & & \\
\hline EC & & \\
\hline ID & & \\
\hline \hline
\end{tabular}

TABLE VI: COMPARISON OF WEAKNESSES AND OPPORTUNITIES (WO)

Weaknesses

ED EP

IX

EX

EA

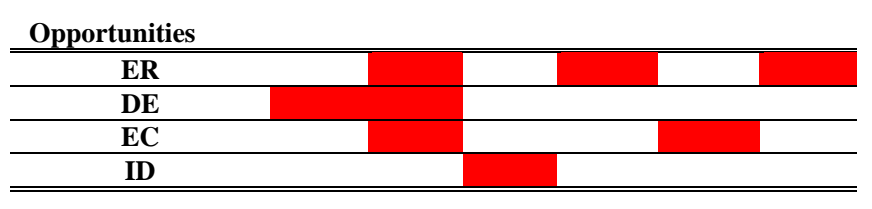

TABLE VII: COMPARISON OF WEAKNESSES AND STRENGTHS (WS)

\begin{tabular}{ccccccc}
\hline \hline Weaknesses & & & & & & \\
Strengths & ED & EP & IX & EX & EA & UI \\
\hline \hline LI & & & & & \\
\hline EE & & & & & \\
\hline RA & & & & & \\
\hline EU & & & & \\
\hline \hline
\end{tabular}

The results show that the average for internal factor is 1.84 and for external factor is 2.98 ; these results indicate that issuance of environmental insurance policy at present time is not able to change threats to opportunities (2.98) and weakness to strengths (1.84). Therefore SWOT model is used to establish new strategies by using strengths, weaknesses, opportunities and threats in pairs to obtain the proper strategy.[12] (Table V to X).

\begin{tabular}{ccccc}
\multicolumn{4}{c}{ TABLE VIII: COMPARISON OF STRENGTHS AND THREATS (ST) } \\
\hline \hline Strengths & LI & EE & RA & EU \\
Threats & & & & \\
\hline \hline IR & & & \\
\hline EF & & & \\
\hline EM & & & \\
\hline PI & & \\
\hline IX
\end{tabular}

TABLE IX: COMPARISON OF WEAKNESSES AND THREATS (WT) Weaknesses

\begin{tabular}{|c|c|c|c|c|c|c|}
\hline Threats & ED & EP & IX & EX & EA & UI \\
\hline 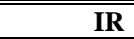 & & & & & & \\
\hline EF & & & & & & \\
\hline EM & & & & & & \\
\hline PI & & & & & & \\
\hline IX & & & & & & \\
\hline
\end{tabular}

Shaded cells in each table indicate the interface between strategic factors. [13]. by analyzing these interfaces and also consulting insurance experts, appropriate strategies were defined as given in Table XI. 
TABLE X: COMPARISON OF OPPORTUNITIES AND THREATS (OT) Opportunities

ER DE EC ID

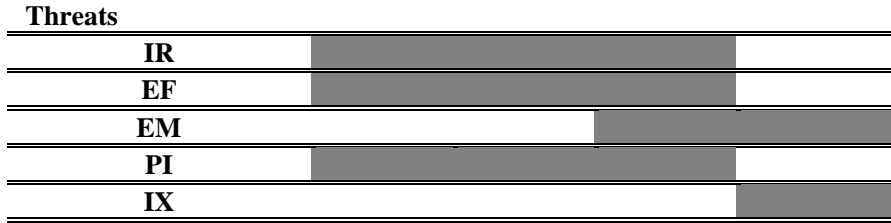

TABLE XI: DEVELOPING INTEGRATED STRATEGIES

\begin{tabular}{cl}
\hline \hline Combined strategies & \multicolumn{1}{c}{ Strategy Description } \\
\hline \hline SO1 & $\begin{array}{l}\text { Using legal tools to assess environmental risks } \\
\text { in different industries }\end{array}$ \\
\hline SO2 & $\begin{array}{l}\text { Developing civil liability insurance according to } \\
\text { the insurance industry's' development }\end{array}$ \\
\hline SO3 & $\begin{array}{l}\text { Improving supervisory structure of } \\
\text { environmental department in order to be able to } \\
\text { implement to environmental insurance policy }\end{array}$ \\
\hline WO1 & $\begin{array}{l}\text { Raising awareness on environmental accidents } \\
\text { outcomes }\end{array}$ \\
\hline WO2 & $\begin{array}{l}\text { Insurance companies should higher } \\
\text { environmental experts }\end{array}$ \\
\hline WO3 & $\begin{array}{l}\text { Developing administrative infrastructure for } \\
\text { issuance of environmental insurance policy }\end{array}$ \\
\hline WS1 & $\begin{array}{l}\text { Giving priority to environmental issues in } \\
\text { industries }\end{array}$ \\
\hline ST1 & $\begin{array}{l}\text { Developing environmental protection culture } \\
\text { through reconstruction of education system. }\end{array}$ \\
\hline WT1 & $\begin{array}{l}\text { Providing obligatory rules in order to provide } \\
\text { environmental liability insurance policy }\end{array}$ \\
\hline OT1 & Review of environmental crime law \\
\hline \hline
\end{tabular}

In order to assess the attractiveness of each strategic factor and related strategy, the QSPM matrix is formed as given in Table XII.

In the first column of the QSPM matrix, list of organizational and strategic factors are given which include all the strengths, weaknesses, opportunities and threats, exactly in accordance with the IFE and EFE matrices. In the second column, the final score of each item is written using calculated figures given in IFE and EFE matrices. The rows of QSPM matrix are included a variety of different strategies such as SO, WT, ST, WO as defined earlier. [14]

Each column of the QSPM matrix is divided into two columns. One is called the Attractiveness Score (AS); and the second is called Total Attractiveness Score (TAS).

TAS can be calculated by multiplying each AS to its final score. The AS itself has valued from 1 to 4 that is depending on its effect and the importance within that strategy. Score 1 is given when there is no attraction and 4 if it is highly attractive.

By comparison of the results of the summation of TAS from each strategy, the higher score can indicate a more attractive strategy [15].

TABLE XII: COMPARING DIFFERENT STRATEGIES FOR PRIORITIZATION

\begin{tabular}{|c|c|c|c|c|c|c|c|c|c|c|c|c|c|c|c|c|c|c|c|c|c|}
\hline \multirow{2}{*}{$\begin{array}{l}\text { Strategic } \\
\text { factors }\end{array}$} & \multirow{2}{*}{$\begin{array}{l}\text { Final } \\
\text { score }\end{array}$} & \multicolumn{2}{|c|}{ OT1 } & \multicolumn{2}{|c|}{ WT1 } & \multicolumn{2}{|c|}{ ST1 } & \multicolumn{2}{|c|}{ WS1 } & \multicolumn{2}{|c|}{ WO3 } & \multicolumn{2}{|c|}{ WO2 } & \multicolumn{2}{|c|}{ WO1 } & \multicolumn{2}{|c|}{ SO3 } & \multicolumn{2}{|c|}{$\mathrm{SO} 2$} & \multicolumn{2}{|c|}{ SO1 } \\
\hline & & $\overline{\mathrm{AS}}$ & TAS & AS & TAS & $\overline{\mathrm{AS}}$ & TAS & $\overline{\mathrm{ASS}}$ & TAS & $\overline{\mathrm{AS}}$ & TAS & $\overline{\mathrm{AS}}$ & TAS & $\overline{\mathrm{AS}}$ & TAS & $\overline{\mathrm{AS}}$ & TAS & $\overline{\mathrm{AS}}$ & TAS & AS & TAS \\
\hline$\overline{\mathrm{LI}}$ & 0.056 & 2 & 0.11 & 3 & 0.16 & 1 & 0.05 & 1 & 0.05 & 3 & 0.16 & 3 & 0.16 & 2 & 0.11 & 1 & 0.05 & 4 & 0.22 & 2 & 0.11 \\
\hline $\mathrm{EE}$ & 0.047 & 3 & 0.14 & 2 & 0.09 & 4 & 0.18 & 4 & 0.18 & 3 & 0.14 & 4 & 0.18 & 3 & 0.14 & 3 & 0.14 & 2 & 0.09 & 3 & 0.14 \\
\hline RA & 0.056 & 1 & 0.05 & 2 & 0.11 & 2 & 0.11 & 2 & 0.11 & 3 & 0.16 & 1 & 0.05 & 4 & 0.22 & 1 & 0.05 & 3 & 0.16 & 4 & 0.22 \\
\hline EU & 0.044 & 2 & 0.08 & 2 & 0.08 & 4 & 0.17 & 2 & 0.08 & 3 & 0.13 & 4 & 0.17 & 2 & 0.08 & 2 & 0.08 & 1 & 0.04 & 2 & 0.08 \\
\hline ED & 0.059 & 2 & 0.11 & 2 & 0.11 & 2 & 0.11 & 2 & 0.11 & 3 & 0.17 & 4 & 0.23 & 4 & 0.23 & 2 & 0.11 & 2 & 0.11 & 4 & 0.23 \\
\hline $\mathrm{EP}$ & 0.05 & 2 & 0.10 & 2 & 0.10 & 3 & 0.15 & 4 & 0.23 & 2 & 0.10 & 2 & 0.10 & 4 & 0.23 & 3 & 0.15 & 1 & 0.05 & 2 & 0.10 \\
\hline IX & 0.047 & 2 & 0.09 & 4 & 0.18 & 2 & 0.09 & 2 & 0.09 & 3 & 0.14 & 4 & 0.18 & 3 & 0.14 & 2 & 0.18 & 1 & 0.04 & 1 & 0.04 \\
\hline $\mathrm{EX}$ & 0.047 & 1 & 0.04 & 2 & 0.09 & 3 & 0.14 & 1 & 0.04 & 3 & 0.14 & 4 & 0.18 & 3 & 0.14 & 2 & 0.09 & 1 & 0.04 & 2 & 0.09 \\
\hline EA & 0.056 & 1 & 0.05 & 2 & 0.11 & 3 & 0.16 & 2 & 0.11 & 2 & 0.11 & 3 & 0.16 & 4 & 0.22 & 2 & 0.11 & 2 & 0.09 & 4 & 0.22 \\
\hline UI & 0.053 & 2 & 0.10 & 2 & 0.10 & 1 & 0.05 & 2 & 0.10 & 2 & 0.10 & 2 & 0.10 & 3 & 0.17 & 1 & 0.05 & 3 & 0.17 & 1 & 0.05 \\
\hline ER & 0.056 & 4 & 0.22 & 2 & 0.11 & 2 & 0.10 & 3 & 0.16 & 3 & 0.16 & 2 & 0.11 & 2 & 0.11 & 2 & 0.11 & 2 & 0.11 & 2 & 0.11 \\
\hline$\overline{\mathrm{DE}}$ & 0.053 & 4 & 0.21 & 4 & 0.21 & 3 & 0.17 & 3 & 0.17 & 2 & 0.10 & 2 & 0.10 & 3 & 0.17 & 4 & 0.21 & 3 & 0.17 & 4 & 0.21 \\
\hline $\mathrm{EC}$ & 0.059 & 4 & 0.23 & 4 & 0.23 & 2 & 0.11 & 3 & 0.17 & 2 & 0.11 & 2 & 0.11 & 3 & 0.17 & 4 & 0.23 & 1 & 0.05 & 4 & 0.23 \\
\hline ID & 0.047 & 2 & 0.09 & 3 & 0.14 & 1 & 0.04 & 1 & 0.04 & 4 & 0.18 & 3 & 0.14 & 2 & 0.09 & 2 & 0.09 & 4 & 0.18 & 2 & 0.09 \\
\hline IR & 0.059 & 3 & 0.17 & 4 & 0.23 & 3 & 0.17 & 2 & 0.11 & 3 & 0.17 & 4 & 0.23 & 2 & 0.11 & 4 & 0.23 & 3 & 0.17 & 4 & 0.23 \\
\hline $\mathrm{EF}$ & 0.053 & 2 & 0.10 & 3 & 0.16 & 3 & 0.16 & 2 & 0.10 & 2 & 0.10 & 2 & 0.10 & 2 & 0.10 & 3 & 0.16 & 1 & 0.05 & 3 & 0.17 \\
\hline EM & 0.044 & 2 & 0.08 & 2 & 0.08 & 2 & 0.08 & 2 & 0.08 & 3 & 0.13 & 1 & 0.04 & 2 & 0.08 & 2 & 0.08 & 2 & 0.08 & 2 & 0.08 \\
\hline
\end{tabular}




\begin{tabular}{|c|c|c|c|c|c|c|c|c|c|c|c|c|c|c|c|c|c|c|c|c|c|}
\hline PI & 0.043 & 3 & 0.13 & 3 & 0.13 & 4 & 0.17 & 3 & 0.13 & 2 & 0.08 & 4 & 0.17 & 3 & 0.13 & 3 & 0.13 & 1 & 0.04 & 3 & 0.13 \\
\hline IX & 0.059 & 2 & 0.11 & 2 & 0.11 & 2 & 0.11 & 3 & 0.17 & 4 & 0.23 & 2 & 0.11 & 2 & 0.11 & 2 & 0.11 & 3 & 0.17 & & 0.11 \\
\hline SUM & & & 2.21 & & 2.53 & & 2.32 & & 2.23 & & 2.57 & & 2.62 & & 2.57 & & 2.36 & & 2.03 & & 2.64 \\
\hline
\end{tabular}

\section{CONCLUSION}

Prioritization of TAS from different strategies show that we need set prioritized compound strategies at any area as SWOT as below:

1) Raising awareness of environmental accidents outcomes (WO1)

2) Using legal tools to evaluate environmental risks in different industries (SO1)

3) Insurance companies require environmental experts (WO2)

4) developing administrative infrastructure for issuance of environmental insurance policy (WO3)

5) Providing obligatory rules in order to provide environmental liability insurance policy (WT1)

6) Developing supervisory structure of environmental department in order to issue environmental insurance policy (SO3)

The insurance companies should provide the necessary tools and infrastructure in order to be able to execute these strategies. In order to do so, it is necessary to consider some specific issues such as laws, regulations, social and economic conditions of each society.

\section{ACKNOWLEDGMENT}

I appreciate my dear professor dr.madjid abbaspour to direct and encourage me during writing this paper.

\section{REFERENCES}

[1] Braysvn, M. John, and A. Mnvryan, "Strategic planning management and planning organization," Translation, pp. 120-125, July 2003.

[2] S. Sehat, Parizad, and Jesus, "Using a network analyzer in the process of analyzing the strengths, weaknesses, opportunities, threats," Iran Insurance Company Case Study, vol. 4, pp. 47-54, Jan. 2008.
[3] M, Light, "Insurance risk of environmental pollution," Central Insurance of Iran, no. 2, pp. 59-65, Oct. 2007.

[4] M, Light, "Insurance risk of environmental pollution," Central Insurance of Iran, no. 2, pp. 20-25, Oct. 2008.

[5] M. Olfathi, "Environmental and insurance," Central Insurance of Iran, no. 1, 1370, pp. 44-53, July 2010.

[6] R. Mosadegh, "Liability insurance for directors and heads of institutions," no. 36, pp. 19-30, Jan 2007.

[7] H.-H. Chang and W.-C. Huang, "Application of quantification SWOT analytical method," vol. 43, pp. 32-45, 2006.

[8] R. K. Shrestha, R. R. Janaki, and Alavalapati, "Exploring the potential for silvopasture adoption in south-central Florida: An application of SWOT - AHP method," vol. 81, pp. 1105-1120, 2004.

[9] E. Walter et al., "The chief strategy officer," Harvard Business Review, October 2007.

[10] B. Peter, Purohit, and Devararat, "Strategic planning in unstable environments," Long Range Planning, vol. 40, no. 1, Feb. 2007.

[11] David and Fred, "The strategic planning matrix - A quantitative approach," Long Range Planning, vol. 19, no. 5, p. 102, October 1986

[12] David and Fred, "Computer-assisted strategic planning in small businesses," Journal of Systems Management 36, no. 7, pp. 24-34, July 1985.

[13] McGinnis and Michael, "The key to strategic planning: integrating analysis and intuition," Sloan Management Review 26, no. 1-49, Fal 1984.

[14] Mintzberg and Henry, "Crafting strategies," Harvard Business Review, pp. 66-75, July-August, 1987.

[15] M. Henry and J. Waters, "Of strategies, deliberate and emergent," Strategic Management Journal vol. 6, no. 2, pp. 257-272.

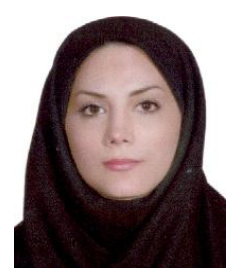

Mahnaz Mirza Ebrahm Tehrani was born in Iran on October 5, 1975, she got the mathematics and physics diploma in 1993; the bachelor of occupationa health and safety in 1999; the MSc in environmental economics in 2007; and the $\mathrm{PhD}$ in environmental management in 2011

She is HSE director at Iran Marine Industrial Company (10 years), faculty member at Islamic Azad University-North Tehran Branch (2007 up to now).

She had 3 books in occupational risk assessment guidance, natural resources and environmental economics and occupational health management. 